\title{
Latin American Integration Route and the State of Mato Grosso do Sul: productive characterization, threats, and possibilities of promotion
}

\author{
Rota de Integração Latino-Americana e o estado de Mato Grosso do Sul: \\ caracterização produtiva, ameaças e possibilidades de fomento
}
Ruta de Integración Latinoamericana y el estado de Mato Grosso do Sul: caracterización productiva, amenazas y posibilidades de promoción

\author{
Mateus Boldrine Abrita ${ }^{1}$ \\ Daniel Amorim Souza Centurião \\ Angelo Rondina Neto $^{3}$ \\ Rafaella Stradiotto Vignandi ${ }^{4}$
}

Received on 23 Sept. 2021; revised and approved on 6 Aug. 2021; accepted on 30 Aug. 2021 DOI: http://dx.doi.org/10.20435/inter.v22i4.3168

\begin{abstract}
The Latin American Integration Route (RILA) corresponds to the materialization of an old desire to integrate the peoples of South America. This route will connect important municipalities in Brazil, Paraguay, Argentina, and Chile. In the state of Mato Grosso do Sul (MS), it will connect important municipalities, and bring opportunities and threats. The objective of the study was to analyze the productive structure of the municipalities in Mato Grosso do Sul that will be directly affected by the RILA to better understand this process. For this purpose, we used an Exploratory Spatial Data Analysis (Spatial EDA) and the spatial Locational Quotient (sLQ) of the sectorial jobs of the municipalities of the State. The results point out a spatial inequality in productive sectors, delimiting "sectorial islands". In the industrial sector, the northeastern regions and the surroundings of the capital, Campo Grande, stand out. The northeast region of the State also stands out in the Civil Construction sector and, together with the north-central part of the MS, in the agriculture and livestock sector. In the trade sector, the southern region of the MS stands out, with proximity to Paraguay. In the services sector, there is a relative concentration in the capital and the extreme south of the State. In conclusion, we point out the urgent need for public policies to expand opportunities and mitigate the threats of integration managed by the route.
\end{abstract}

Keywords: productive integration; regional development; public policies; Latin American Integration Route (RILA).

Resumo: A Rota de Integração Latino Americana (RILA) corresponde à materialização de um desejo antigo de integrar os povos da América do Sul. Tal caminho interligará importantes municípios do Brasil, Paraguai, Argentina e Chile. No Estado do Mato Grosso do Sul, ela ligará importantes municípios, trazendo oportunidades e ameaças. O objetivo do estudo foi analisar a estrutura produtiva dos municípios sul mato-grossenses que serão afetados diretamente pelo trajeto da RILA para melhor entender esse processo. Para tanto, utilizouse análise exploratória dos dados espaciais (AEDE) e o Quociente Locacional Espacial (QLS) dos empregos setoriais dos municípios do Estado. Os resultados apontam uma desigualdade espacial nos setores produtivos, delimitando "ilhas setoriais". No setor industrial, a região nordeste e o entorno da capital, Campo Grande, se destacam. A região nordeste do Estado também se destaca no setor da Construção Civil e, conjuntamente com a parte centro-norte do MS, no setor agropecuário. No setor do comércio, se destaca a região sul do MS, com proximidade do Paraguai. Já no setor de serviços é verificada uma concentração relativa na capital e no extremo sul do Estado. Conclui-se com a urgência de políticas públicas que ampliem as oportunidades e mitiguem as ameaças da integração gestada pela rota

Palavras-chave: integración productiva; desarrollo regional; políticas públicas; Ruta de la Integración Latinoamericana (RILA).

\footnotetext{
${ }^{1}$ Universidade Estadual de Mato Grosso do Sul (UEMS), Campo Grande, Mato Grosso do Sul, Brasil.

${ }^{2}$ West Virginia University, Morgantown, West Virginia, United States of America.

${ }^{3}$ Universidade Estadual de Londrina (UEL), Londrina, Paraná, Brasil.

${ }^{4}$ Universidade Federal de Rondonópolis (UFR), Rondonópolis, Mato Grosso, Brasil.
} 


\begin{abstract}
Resumen: La Ruta de la Integración Latinoamericana (RILA) corresponde a la materialización de un antiguo anhelo de integración de los pueblos de Sudamerica, que conectará importantes municipios de Brasil, Paraguay, Argentina y Chile. En el estado de Mato Grosso do Sul, vinculará municipios importantes, trayendo oportunidades y amenazas. El objetivo del estudio fue analizar la estructura productiva de los municipios del Mato Grosso do Sul que serán directamente afectados por la ruta RILA para comprender mejor este proceso. Para ello, se utilizó el análisis exploratorio de datos espaciales (AEDE) y el Cociente de Ubicación Espacial (CV) de los trabajos sectoriales en los municipios del Estado. Los resultados apuntan a una desigualdad espacial en los sectores productivos, delimitando "islas sectoriales". En el sector industrial destacan las regiones del noreste y alrededores de la capital, Campo Grande. La región noreste del estado también se destaca en el sector de Construcción Civil y, junto con la parte centro-norte de MS, en el sector agrícola. En el sector comercial, se destaca la región sur de MS, con cercanía a Paraguay. En el sector servicios, existe una concentración relativa en la capital y en el extremo sur del estado. como conclusión tenemos la urgencia de políticas públicas que amplíen oportunidades y mitiguen las amenazas de integración que genera la ruta.
\end{abstract}

Palabras clave: integração produtiva; desenvolvimento regional; políticas públicas; Rota de Integração Latino Americana (RILA).

\title{
1 INTRODUCTION
}

The possibility of a new productive route linking the Port of Santos in the State of São Paulo in Brazil to the ports of Antofagasta and Iquiqui in Chile, passing through the State of Mato Grosso do Sul (MS), Paraguay, and Argentina, has been providing an intense debate about opportunity windows for socio-economic development. Also, challenges and complex issues arise in this context. The so-called Bioceanic Corridor (CB), Bioceanic Route (RB) or also named Latin American Integration Route (RILA), is a transport corridor still under construction that has been providing a great academic and political debate.

According to Mato Grosso do Sul (2019) this transport corridor will result in gains such as reduction of cost and time in transport, storage, and inventory; promotion of cargo and passenger circulation; stimulus for the development of strategic productive partnerships; stimulus for the development of productive integration projects; and adding value in countries of origin and destination, as well as in transit countries. In this context, Castro (2019) argues that a meeting took place at the end of 2015 in which several countries sent representatives including heads of state from Southern Common Market (Mercosul). On this occasion, workgroups were formed to carry out technical studies and assist in the construction of this corridor.

Considering that the corridor construction project is underway, to obtain an initial socioeconomic understanding, Constantino et al. (2019) carried out a characterization based on economic indicators of municipalities in Mato Grosso do Sul (MS) such as Gross Domestic Product (GDP), GDP per capita, population; tax collection; sectoral gross value-added; and main, secondary, and tertiary economic activity. After analyzing these indicators, the authors point out that the municipality of Porto Murtinho is the most vulnerable from an economic and social point of view, with low production dynamics, in addition to an economy based on livestock and public administration resources, despite the tourism sector growth. Therefore, they highlight the importance of public and private development policies to maximize the possibility of beneficial results for the entire state of MS.

In this context of socioeconomic challenges, especially for the MS state, in which it is necessary to foster the potentialities and minimize negative impacts, the main objective of the present work is to analyze the productive structure of the municipalities in the Mato Grosso do Sul state that will be directly affected by the RILA path. Therefore, the work is divided into four 
parts, in addition to this introduction, we outline a contextualization of RILA in the context of regionalization of economic development. Afterward, we analyze the methodological aspects, later we present the analysis and discussion of the results and the final considerations.

\section{THE RILA AND THE LATIN AMERICAN INTEGRATION}

The desire to integrate the Andean peoples, as well as South America, is not new. According to Ferreira, Castilho e Oliveira (2019) since the creation of Mercosul, there is an interest in physically interconnecting the countries, mainly to connect the Pacific Ocean to the Atlantic. Some important cities will be directly influenced by this corridor, such as: Campo Grande and Porto Murtinho in the state of MS in Brazil; Carmelo Peralta, Mariscal José Félix Estigarribia, Boquerón and Pozo Hondo in Paraguay; Misión La Paz, Tartagal, Jujuy and Salta in Argentina; and Mejillones and Iquique in Chile. It is also important to highlight the port of Antofagasta in Chile. As for cultural aspects, Ferreira, Castilho e Oliveira (2019) point out that Brazil, Paraguay, and Argentina have elements in common such as gastronomic and religious habits, dances, folkloric presentations, and some indigenous heritages. Hence, in addition to providing economic integration, RILA will be able to generate an intersection of cultural points.

According to Ferreira, Castilho e Oliveira (2019) and the Conselho Sul-Americano de Infraestrutura e Planejamento [COSIPLAN] (2018), the road interconnection process in the Americas had an important initiative by the COSIPLAN This work front aims to integrate the South American Regional Infrastructure (IIRSA) to foster more efficient processes concerning infrastructure, transport, and logistics in South America. The meeting of the Presidents of South American countries that took place in August 2000 in the city of Brasília, Brazil resulted in a relevant milestone in this area. On this date, it was created an integration and cooperation plan. The focus was the Integration and Development Axes of South America, which underwent some changes in 2004.

According to Asato et al. (2019), the bioceanic road path will have approximately two thousand and two hundred kilometers, assuming its beginning in the city of Campo Grande (MS). It continues until the North of Chile, where the production outflow ports are located. The RILA expedition, carried out by the MS state entrepreneurs and representatives of public institutions, was an important milestone for this project. It took place from August 25th to September 2 nd, 2017. One of the most viable routes was the one indicated in Figure 1 (ASATO et al., 2019).

Therefore, to make RILA viable, it will be necessary to build a bridge connecting Porto Murtinho (2) to the municipality of Carmelo Peralta (3), the frontier between Brazil and Paraguay, as shown in the numbered points in Figure 1. Mapping the itinerary in its entirety, it is possible to notice the passage through 12 cities along the entire corridor. The bridge construction connecting Porto Murtinho (2) to Carmelo Peralta (3) in Paraguay is the first international treaty ever signed. 
Figure 1 - Path of the Latin American Integration Route (RILA)

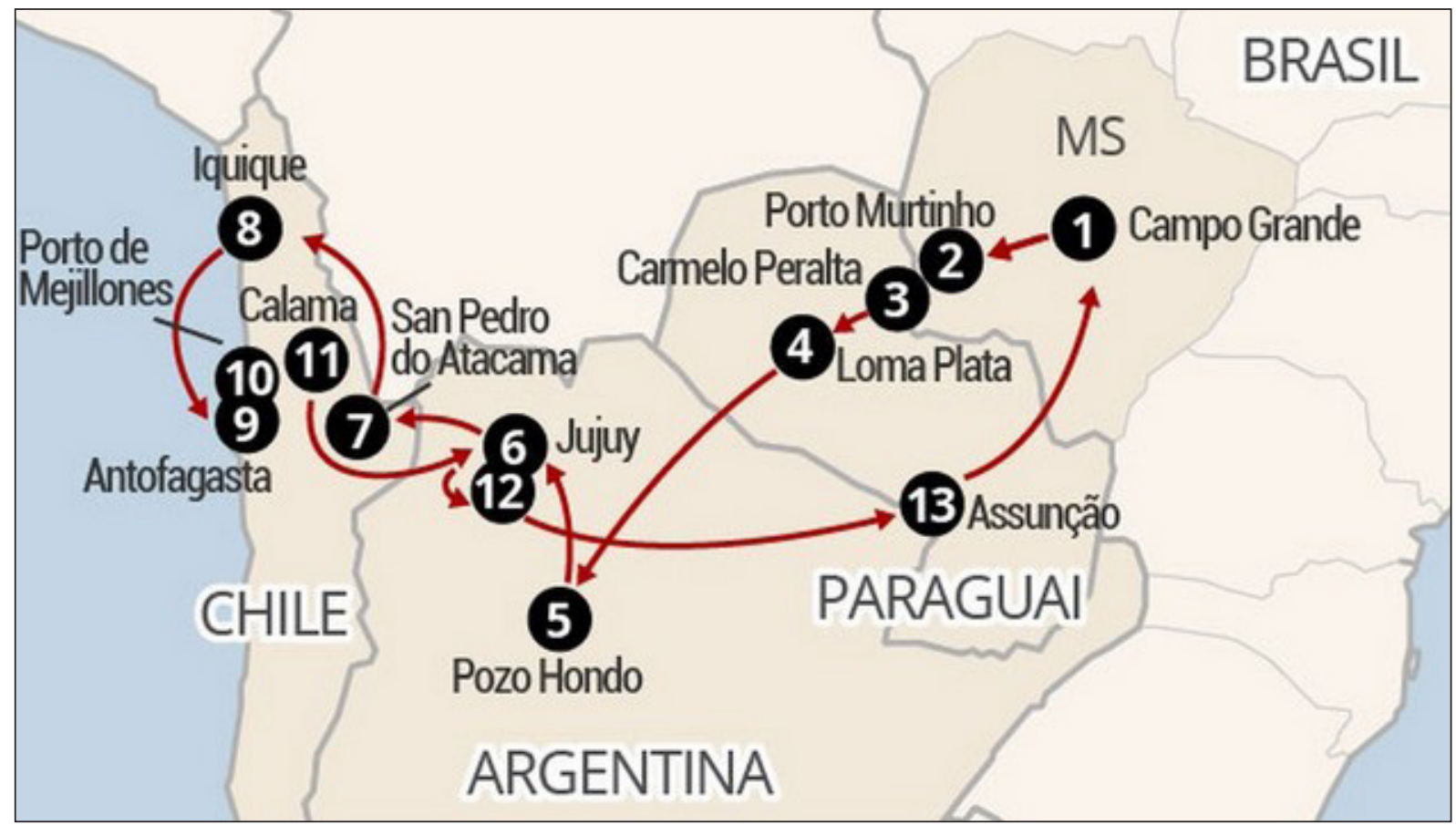

Source: Viegas (2017 apud ASATO et al. 2019).

According to the Itaipu (2019), the work on the bridge should be completed in 2023, with an investment of around US\$ 75 million and, according to expectations, it will have a length of 680 meters, with 380 meters with free spans and 22 meters high, with two towers over 100 meters high and viaducts measuring 150 meters at both heads, this with pillars that allow the circulation of large vehicles. The generation of more than a thousand jobs is expected in this project. Therefore, the expectation is that in 2023 the flow of cargo and people will already be made possible after the completion of these constructions.

\section{1 The regionalization of development}

Since the 1970s, economic development has presented a growing regional perspective. As Cavalcante (2008) presents, a diverse set of approaches and understandings of regional analysis emerged from that decade onwards ${ }^{5}$. First, the structural transformations verified after the 1970s in the capitalist system itself, emerging a process of "globalization of capital" (see CHESNAIS, 1995) and the weakening of National States; giving greater prominence to the regions as a space for analysis. Second, the emergence of more flexible modes of production, such as Toyotism and Just in time, leading to an emphasis on global production chains and, therefore, greater emphasis

\footnotetext{
${ }^{5}$ Among these, Cavalcante (2008) highlights those who work with an evolutionary perspective, in an analysis of Regional Innovation Systems and Local Productive Arrangements (LPAs) (e.g. EHRNBERG; JACOBSSON, 1997; CASSIOLATO; SZAPIRO, 2002); authors who emphasize the analysis of industrial districts in a context of flexible specialization (e.g. MARKUSEN, 1995); authors who emphasize "innovative environments", such as the European Research Group studies on innovative Millieus (e.g. MAILLAT, 1995); those dealing with regionalization of theories of industrial organization (e.g. STORPER, 1994); authors who emphasize business management and the formation of business clusters (e.g. PORTER, 1980; 1998); and, finally, authors who consider increasing returns to scale and their effects on spatial phenomena (e.g. KRUGMAN, 1998; FUJITA, KRUGMAN; VENABLES, 2000).
} 
on regions and their integration movements. Third, a set of transformations of technical scope, from the expansion of academic production on the regional economy and advances in other areas, such as econometrics and industrial organization.

In this context, the growing interest in the study of localized and specialized productive agglomerations, called clusters, agglomerations, or Local Productive Arrangements (APLs), gain relevance for economic geographers, economists, and public policymakers. In this context, the works of Michael Porter, especially in the 1980s and 1990s, formed a standard concept for the academy. Several public policy managers around the world have been using Porter's concepts as a foundation for the national and regional promotion of local competition, innovation, and growth.

As admitted by Porter (1990), the concept of specialized industrial location dates back to Marshall (1890), with his reflection on the "Concentration of specialized industries in certain locations". For Marshall (1890), localized concentration was based on a triad of external economies: availability of skilled workforce, high support from auxiliary trades (cooperation between participants), and the specialization of different companies at different stages of production. Porter (1990) argues that the intensity of interaction between firms is reinforced if they are located close to each other (or clustered). The agglomeration process (clustering) and the intense exchange between different clusters also help to improve the dynamics between these industries since they are geographically concentrated. Therefore, there is an affinity between Porter's competitive process and Marshall's grouping of local firms related to external economies of industrial location.

Porter's (1990) cluster concept is aimed at a global focus on the determinants of competitiveness (of companies, industries, countries, and now, locations). The cluster concept has become widely accepted by the academic world in general, the formulators and managers of public policies for regional development as a model or theory rigorously tested and evaluated. Globally, the concept has been used to refer to nationally linked industrial groups and companies, especially concerning interdependent businesses, and spread over several different locations within the same country, without an evident geographic concentration ${ }^{6}$. Elsewhere, however, the term "regional cluster" is used as an alternative form (BAPTISTA; SWANN, 1998; ENRIGHT; FFOWCS-WILLIAMS, 2001).

According to Glasmeier (2000), the conceptual application rules are not the same. There is a link that breaks down in the local competitive advantage process. The benefits realized from a geographically close grouping seem to be specific to certain industrial sectors and in certain periods of their development, in some localities, taking place under particular conditions. When analyzing the distribution of innovative commercial activity in the United States, Audretsch (1998) and Feldman (2000) concluded that the propensity to form clusters is greater in those industries with a high dependence on new economic knowledge - as is the case for those industries with high research and development (R\&D) and skilled workforce. The dominant view is that the grouping (or cluster) is more significant, especially for sectors that are dependent on tacit or informal knowledge, often presented at a pre-commercialization stage (AUDRETSCH, 1998; KEEBLE; WILKINSON, 2000).

An additional perspective to this discussion on the regional literature of agglomeration economies is the theoretical relationship between the productive clustering process and the network theory. One of the precursors of discussions about which are the most relevant places

\footnotetext{
${ }^{6}$ This was the original use of the name given by Porter (1990) for the "competitive diamond".
} 
for the location of companies regarding their competitiveness and network analysis was Castells (1996). The author brings two important concepts: the "space of places", which refers to issues of location of learning and innovation (i.e., to be in the right place can generate a favorable impulse for companies); and the "space of flows", which conforms to the idea that networks are important instruments for transferring and diffusing knowledge, therefore being created and organized for the constant movement of people, goods, and information. It should be noted that the space of flows is not directed to move things from one place to another, but to keep moving around, so that participating in a network becomes fundamental.

Castells' (1996) concept can be associated with the cluster approach presented above. Since Marshall (1890), the literature on the subject is based on the understanding that regions are engines of innovation and economic development, as they generate benefits to companies from a favorable industrial environment and its knowledge externalities. This occurs because tacit knowledge moves more easily over short distances, and the common institutions are recognized in clusters promoting the effective transfer of knowledge. The connections between local networks and specialized companies form an essential link in the cluster approach. This contributes to the success of regional economic development. As lammarino and McCann (2006) point out, a large part of successful clusters became increasingly associated with the presence of networks that, in addition to helping to reduce transaction costs, favored the dissemination of knowledge, to increase the probability of innovative processes.

Therefore, social proximity is considered a driving force for the formation of networks. According to Sorenson (2003), companies are more likely to connect to other companies' individuals with which they are socially interconnected. Issues such as a shared work past, for example, are a source of social connection between the individuals. Hence, relationships with old contacts are often maintained when an employee leaves one company to work in another (work mobility) or to start his own company (via spin-off). This can lead to the creation of knowledge networks between the companies involved. As mobility and spin-off processes are, essentially, local phenomena, such resources are more susceptible to the formation of local networks.

In a macro context, the analysis of networks and clusters also relies on the effect of the past. The cognitive concept of lock-in corresponds to dense parts of a network in a cluster being locked in certain pre-established ways, with the lack of new knowledge. According to Glaeser et al. (1992), sectoral specialization in a region is good practice to verify whether a more diversified regional economy generates more knowledge spillovers (i.e., Jacobian externalities). Studies on agglomeration economies complement this discussion by analyzing how new knowledge can flow between different regions through local connections between organizations.

More recent analyzes (ORGANISATION FOR ECONOMIC CO-OPERATION AND DEVELOPMENT [OECD], 2011a; 2011b; 2012) reinforce the importance of regions as a space to promote broad and continuous improvements in growth and development. For Garretsen et al. (2013), the debate on the topic is relevant, especially for structuring public policies. On the one hand, there is growing awareness of the role regions plays in aggregate growth. On the other hand, it is noticeable that regional development issues involve government decisions and public finance acquisition. In this recent context, we can observe some characteristics to foster the regionalized development process: new forms of governance, regional competition, allocation, and more effective financing. 


\section{METHODOLOGY}

Considering the importance of regional analysis, we used data on the number of jobs per economic activity in each municipality as a proxy for the employment variable. From these data, we calculated a reference indicator that measures productive specialization. This indicator is used for a second procedure to measure the spatial correlation of the data and allow inferences about the effective concentration of economic activities. Finally, we used data from Municipal GDP, GDP per capita, population, Gross Value-Added (GVA) by large sector, exports, and imports to characterize the municipalities and through which RILA will pass.

\section{1 Databases}

The data used are primarily from jobs, grouped by the Annual List of Social Information (RAIS), by section of the National Classification of Economic Activities (CNAE) 2.0, for the year 2018. These data allowed us to calculate the selected reference indicator, the Locational Quotient (LQ). We highlight that this database only considers formal posts and does not include formal declarations made after the deadline.

In addition to this database, we used sources from the Brazilian Institute of Statistical Geography (IBGE) and prepared regional national accounts in partnership with the State Secretaria de Estado de Meio Ambiente, Desenvolvimento Econômico, Produção e Agricultura Familiar (SEMAGRO). Population estimates from the 2010 IBGE Demographic Census provided population data of each municipality. Finally, we collected export and import data from the Ministry of Industry, Foreign Trade, and Services through COMEX Stat, which is the official platform of foreign trade statistics. Export values are in Free on Board (FOB) dollars.

\section{2 Spatial location quotient}

The LQ is an established measure in the literature related to regional analysis. We performed its calculation using the number of jobs per economic activity in each municipality as a proxy for the employment variable. Its simple intuition aims to explain the participation of the employment in the activity in the total employment of the reference region, which is the sum of employment in the activity of all selected municipalities. The second part of the calculation verifies the participation of the total employment of the activity in the region total employment. It is possible to view the steps in equation 1.

$$
Q L=\left(E_{i j} / E_{i t}\right) /\left(E_{t j} / E_{-} t t\right)
$$

In the equation (1), $E_{i j}$ is equivalent to the employment of sector $i$ in municipality $j ; E_{i t}$ corresponds to total employment of sector $i$ in state $t ; \mathrm{E}_{\mathrm{t} j}$ corresponds to total employment in municipality $j$; and $E_{t t}$ is equivalent to total employment in state $t$. According to Haddad (1985) the indicator can be interpreted as follows, when greater than one, the analyzed region can be considered specialized in that sector; when lesser than one, it is considered non-specialized.

In this work, we chose to use the spatial LQ (sLQ), which is an adaptation of the original indicator that enables the incorporation of space in the analysis and considers the neighborhood 
effects between municipalities. The SLQ follows a calculation structure similar to the traditional indicator but weights its elements by a matrix of spatial weights. In this case, the queen-type matrix is used in the indicator to consider the spatial connection of the municipalities by their vertex or borders. This choice of the matrix type was due to the most appropriate adjustment of the indicators. The formulation for calculating the $S L Q$ follows the pattern presented in equation (2).

$$
s Q L=L Q_{i, j}+\left(\sqrt{L Q_{i}}\right)^{\prime} W\left(\sqrt{L Q_{i}}\right)
$$

It is important to point out that the indicator considers the productive specialization of this economy, considering only the neighborhood effect (presence of neighbors) in the analysis. It is noteworthy that if the neighborhood relationship between regions is disregarded or in the case of regions without neighbors (e.g., islands), the value of the SLQ will be exactly equal to the LQ.

\subsection{Exploratory spatial data analysis - spatial EDA}

Data analysis in space allows the identification of clusters as well as data discrepancies. Anselin (1998) exposes the possibility of using this technique to build global and local autocorrelation measures. In the present work, the implementation of the exploratory analysis allows obtaining a spatial distribution of activities in the municipalities.

The indicators used are the Global and Local Moran's I. The first reveals a general tendency for the formation of data groups or clusters. The second is the most recommended indicator for identifying regional or local standards. It is called the Local Indication Spatial Association (LISA) indicator.

The association analyses are exposed using Moran's scatter diagram, which, according to Anselin (1995), allows the verification of local trends in its four quadrants. Through this representation, it is possible to classify the spatial associations of municipalities and their neighbors. High-High (HH) or Low-Low (LL) patterns signal a positive association between municipalities, while Low-High ( $\mathrm{LH})$ and High-Low $(\mathrm{HL})$ patterns indicate negative association.

\section{RESULTS AND DISCUSSIONS}

We analyzed data in two parts. Initially, we highlight the productive characteristics of the selected municipalities that will be affected by RILA. Subsequently, we carried out the analysis of the SLQ and other proposed spatial indicators. We dialogue the results with the context of RILA implementation.

\subsection{Productive characteristics of selected municipalities}

The municipalities of the MS state have gone through intense population growth in the last twenty years. Such phenomenon is verified essentially in the urban population, except Nioaque and Sidrolândia, which also had a relevant growth in their rural populations. In general, this population growth was accompanied by the emergence of local economies, primarily by the densification of service sectors in response to the local increase in demand as a result of population growth. Subsequently, there is the advance of industrial sectors linked to agribusiness 
that settle locally due to factors of local availability of raw material from agriculture and livestock and the availability of cheap workforce and tax incentives. Nioaque and Porto Murtinho deviate a little from this logic, showing a greater vocation for the service sector.

Analyzing some indicators in a comparative way between the years 2006 and 2018, it is possible to verify some relevant characteristics about the economic structure and formation of the municipalities that compose RILA. Campo Grande, the state capital, presents the largest population contingent and the largest relative participation in MS GDP. This participation is given by the relevant contribution of the trade and services sector and, subsequently, by the industry. The capital presented a positive export balance between 2006 and 2018. The main products in the export agenda were meats, skins and leather, and preparations for animal feed, as well as oils and by-products extracted from soy ${ }^{7}$.

Table 1 - Structural characteristics of municipalities, percentage variation between $2006-2018$ based on selected indicators*

\begin{tabular}{|c|c|c|c|c|c|c|c|c|}
\hline \multirow{2}{*}{ Municipalities } & \multirow{2}{*}{$\begin{array}{c}\Delta \% \text { GDP } \\
\text { MS }\end{array}$} & \multirow{2}{*}{$\begin{array}{c}\Delta \% \\
\text { GDP per capta }\end{array}$} & \multirow{2}{*}{$\begin{array}{l}\Delta \% \\
\text { Pop. }\end{array}$} & \multicolumn{3}{|c|}{$\Delta \%$ Value-added } & \multirow{2}{*}{$\begin{array}{c}\Delta \% \\
\text { Import }\end{array}$} & \multirow{2}{*}{$\begin{array}{l}\Delta \% \\
\text { Export }\end{array}$} \\
\hline & & & & Agric. & Ind. & Serv. & & \\
\hline Campo Grande & -12 & 177 & 16 & 0 & 0 & 0 & 313 & 167 \\
\hline Guia Lopes da Laguna & -8 & 317 & -21 & 56 & 36 & -17 & 0 & 0 \\
\hline Jardim & -16 & 201 & 4 & 10 & 50 & -4 & 0 & -79 \\
\hline Nioaque & -32 & 217 & -22 & 30 & -56 & -5 & 0 & 0 \\
\hline Porto Murtinho & 32 & 115 & 25 & -2 & -25 & 2 & -100 & 0 \\
\hline Sidrolândia & 337.900 & 87 & 91 & 6 & -53 & 16 & 4.030 & -100 \\
\hline Três Lagoas & 41 & 279 & 37 & -41 & 31 & -11 & 60 & 16.012 \\
\hline
\end{tabular}

*Note: value-added, GDP per capita are updated until 2017, it was the last official data released. The others are updated until 2018.

Source: Brasil (s.d.) and Secretaria de Estado de Meio Ambiente, Desenvolvimento Econômico, Produção e Agricultura Familiar [SEMAGRO] (s.d.).

Guia Lopes da Laguna has an economic structure dedicated to the trade and services sector, with emphasis on activities of trade, repair of motor vehicles, accommodation, food, professional, and administrative activities. Over the years, agriculture has specialized in the production of grains, corn, and soybeans; however, it was historically linked to other activities such as the production of cassava and sugar cane. In livestock, the production of milk, honey, and beef cattle raising gain evidence over the years under review. The installed industry is closely linked to livestock, with dairy products, refrigeration plants, and food processing.

The municipality of Jardim has similar characteristics concerning the productive structure of agriculture and livestock, with greater dedication to the beef cattle herd and the production of grains, cassava, and sugar cane. On the other hand, the industry has a significant textile complex and a productive set of food industries such as bakery, ice cream, and other foodstuffs.

Nioaque has a relatively more diversified agricultural structure, with significant production of pineapples, beans, cassava, bananas, soybeans, corn, and sugar cane as the main crop. In livestock production, there is a highlight to the production of milk, honey, and beef cattle

\footnotetext{
${ }^{7}$ The analyzes of the sectoral productive structures of the municipalities presented in this section are based, above all, on the verification of primary data from IBGE/CONAC, SEMAGRO and COMEXSTAT.
} 
and sheep herds. The municipality's industry is quite incipient, with activities concentrated in metallurgy and printing, both consisting of small businesses.

Porto Murtinho stands out in beef cattle, with one of the largest cattle herds in the state. The municipality has its main activity in this sector. Soybeans and corn are the main crops in agriculture but with few planted areas. The industrial park is one of the most incipient among the analyzed municipalities, and in 2018 it had only nine establishments specially dedicated to the manufacture of leather.

The significant population growth both in the city and in the countryside is a relevant characteristic of the municipality of Sidrolândia. It has a very diversified agricultural structure with the plantations of soybean, corn, oats, cotton, and rice as the main protagonists. The cattle, sheep, and swine herds stand out, and the municipality is one of the major producers of sheep and swine in the state. The production of milk and eggs is highlighted in livestock. Its industrial park is equally diverse, with establishments focused on construction, food, metallurgical, reinforced concrete, cement, flour, and dairy activities.

Finally, Três Lagoas is one of the municipalities with the greatest industrial tradition in the state. In agricultural activities, it has a small fruit production, but without great relevance, except in the case of orange production. The industry is quite diversified and dense, with approximately 500 establishments in the year 2018. The main activities are the paper industry and its products, textile, printing, construction, metallurgical production and cement, and other minerals, food and rubber, and plastic materials.

Concerning the value-added, the service sector represents an important sector in most municipalities analyzed. Other highlights are a large relative growth of the industry in Três Lagoas, a relative loss of industry in Sidrolândia, and the relevance of the agriculture and livestock sector in Porto Murtinho.

In summary, service activities play the basic role of the economy in most of the analyzed municipalities, together with agriculture and livestock. In most cases, the latter are carried out extensively and largely originate from the historical heritage of the State's economic formation. The services sector is also linked to historical formation, especially concerning the constitution of cities, where services gain strength. These historical characteristics, added to the still recent population growth and the large territorial areas, promoted a certain sectoral concentration of these economies in most of the municipalities.

There are few cases of municipalities that focused on the industrial sector. Those that did so are very recent projects linked to public development and, in large part, agro-industries linked to local production, a fact that leads local economies to specialization. Dedication to the local market of the service sector demands less fierce competition via prices and lower intensity of transaction costs. Agriculture has been technifying, but it is dedicated to the production of commodities, which imposes products with low value-added, and even those few that are exported are closely linked to the agribusiness. A final issue is that some of the selected municipalities do not have an international trade agenda, which reinforces the local character of their economic logic.

\section{2 Analysis of the location quotient}

The analysis of the $S L Q$ demonstrates the specialization of certain activities in specific regions of the MS state, as pointed out in the previous subsection. As Figure 2 shows, the darker 
colors demonstrate municipalities in which the economic sector is specialized with a higher level of statistical significance ( $0.1 \%$ and $1 \%)$, and lighter shades show a lower level of statistical significance (5\%). The municipalities with white color were not statistically significant for spatial productive specialization.

As this is a spatial indicator, it is possible to consider the neighborhood effects. Therefore, as a municipality specializes, the other municipalities in its surroundings tend to specialize in a particular sector. The municipalities that stand out the most for their level of production specialization in the industrial sector are Paranhos, Sete Quedas, Tacuru, Coxim, Pedro Gomes, São Gabriel, Innocence, Selvíria, and Aparecida do Taboado. In the Civil Construction sector are Três Lagoas, Selvíria, and Innocence. In the commercial sector are Dourados, Ponta Porã, Laguna Carapã and Aral Moreira. The municipality of Innocence and a good proportion of the municipalities in the eastern region of the state deserve attention in the service sector, as well as the municipalities in the extreme south, such as Paranhos, Sete Quedas, and Tacuru. In agriculture, Bandeirantes, Camapuã, Paraíso das Águas, Dourados and Rio Brilhante are highlights.

We verified that of the municipalities affected by RILA (i.e., Três Lagoas, Campo Grande, Sidrolândia, Nioaque, Jardim, Guia Lopes da Laguna, and Porto Murtinho), the municipality of Nioaque does not present significant specialization in any of the economic sectors analyzed; Jardim and Porto Murtinho are specialized only in the industrial sector; Campo Grande and Três Lagoas are specialized in the sectors of trade, services, and civil construction. Finally, Sidrolândia demonstrates specialization in the trade and industry sector and Guia Lopes da Laguna only commerce. 
Figure 2 - Analysis of productive concentration based on the Spatial Location Quotient by large economic sectors
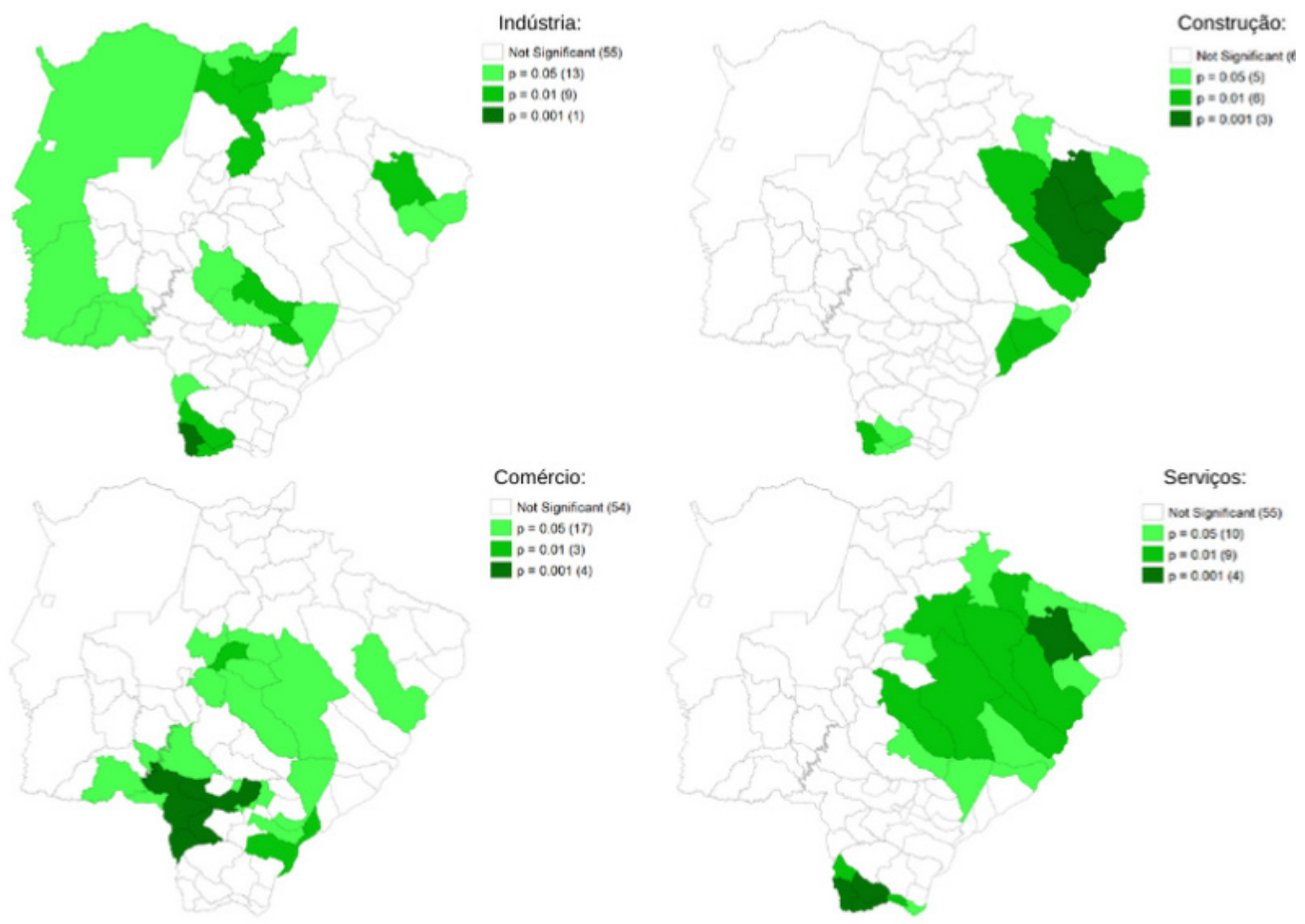

Construçã̃o:

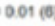

Serviços:
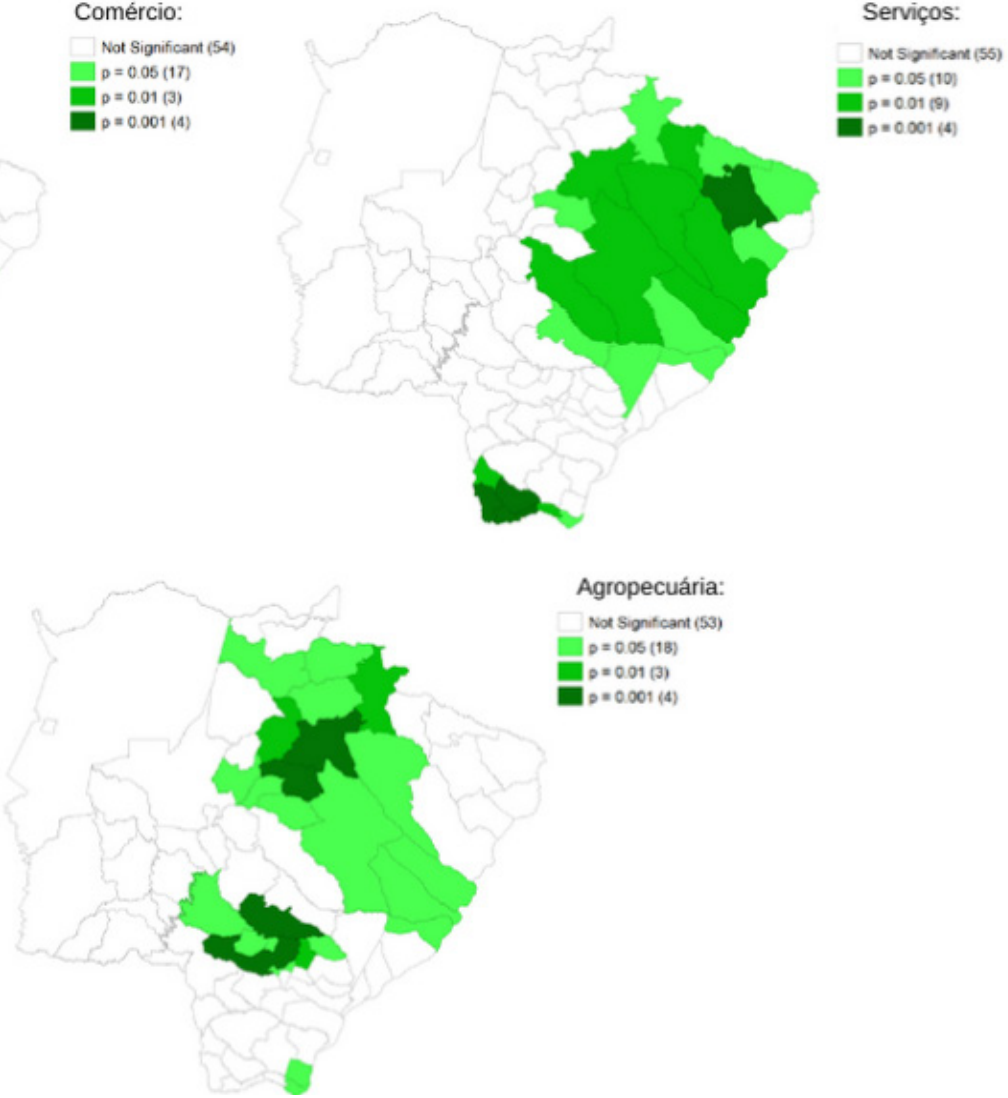

Source: Anselin (1995).

We used the Local Moran's I to assess the spatial correlation, which allowed the precise identification of the neighborhood specialization relationships between the municipalities for the evaluated sectors. The relationships, in this case, are evident as follows: municipalities that demonstrate the AA relationship for a given sector are highly specialized municipalities surrounded by municipalities that are also highly specialized in the same sector. These municipalities are shown in a darker tone in Figure 3.

The municipalities in dark gray tone have low productive specialization in the sector, also surrounded by cities with this characteristic. The ones in a light gray tone have a high productive specialization but are surrounded by municipalities with low specialization in that sector. 
Figure 3-Moran's I by large sector of the economy 2018
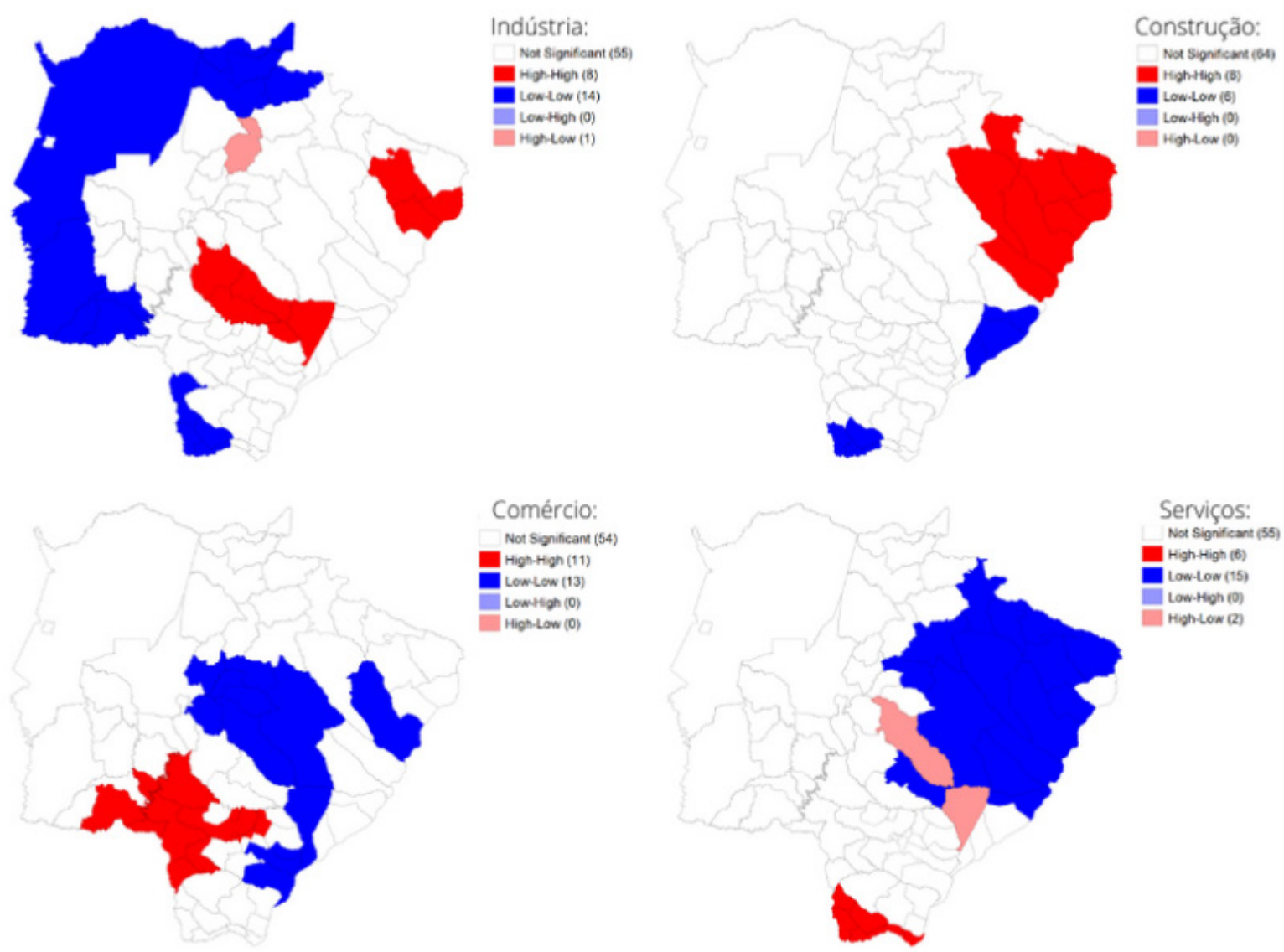

Not Significant (55)

Not Signticant

Low-Low (15)

Low.High (0) HighLow (2)

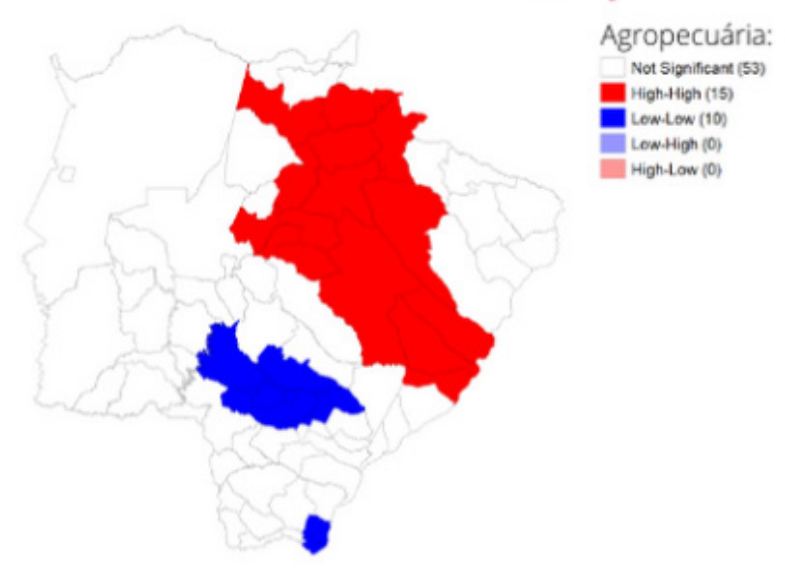

Source: Anselin (1995).

\subsection{Integration by RILA: opportunity or threat to MS?}

Given what was exposed by the data analysis, two structural situations are put on the table for debate. These situations correspond to the specialized model of the productive constitution of the MS, with clearly regionalized sectors determining the heterogeneous economic dynamics of the State. This spatial heterogeneity is confirmed by the extensive number of municipalities with a non-significant spatial indicator, which goes back to low relative levels of specialization and economic dynamics without a driving sector, inducing growth. The imminence of an international productive integration to this model added to the inexistence of a regional policy that provides for it and projects guidelines conditioned to it, an environment of uncertainty is created concerning the success of such an undertaking. 
To better analyze these points, the debate begins with the second question arguing about possible positive and negative points of the productive integration carried out by RILA. Afterward, discuss the first point with some solutions based on regional planning and public policies.

The level of specialization of the municipality and its neighbors reveals the activities that will tend to have the greatest impact with the implementation of RILA. These impacts cannot be fully measured a priori. However, these specialized complexes in each region are expected to have, mainly, a greater capacity to transport their production and/or surpluses. In addition, sectors such as trade and services can benefit from the intensification of flows, hence accomplishing greater volumes of revenue and job creation.

If these industrial and trade sectors are not competitive concerning relative prices, for export or local service, they could suffer negative impacts with the entry of foreign products of lower price and compatible quality. Therefore, with the installation of new entrants, they end up minimizing the positive effects of productive specialization, such as the formation of networks, intensification of investment in R\&D to the detriment of competition via price.

Those clusters of municipalities that are concentrated in agribusiness activities are expected to have their economic potential highlighted, with the gain of competitiveness in terms of cost, by cheaper transportation, in addition to the fast entry into the international market, which, as seen, is not the reality of most selected municipalities. Considering the productive structure of agriculture, the middle and large producers' layer should benefit greatly from the relative reduction in transportation costs. The costs of the purchase of imported inputs will also be reduced and it will not necessarily take place at the domestic level, but there is the possibility of being carried out internationally.

Another possible issue is that there is a significant increase in the general level of international trade between the countries involved. In this regard, there is a gap in the formulation of previous policies that aim for trade agreements within the scope of Mercosul. These trade agreements can avoid predatory competitions, fiscal issues, and the evasion of industrial parks, as has already been happening between Brazil and Paraguay, with the formation of the so-called Paraguayan maquilas.

The increased competition between countries and businesses with such geographical proximity, and with a direct logistical connection, can negatively impact the mechanisms of technology transfer, cooperation, and governance, which are essential for the innovative and productive process. Therefore, such integration can make the integration strategy unfeasible for the regional development of those involved. As it is a physical integration project, it must also include a movement of productive synergy and the formation of networks that strengthen joint production.

It is necessary to reflect deeply on how to integrate the heterogeneous and specialized productive structure in the current context of MS, characterized by sector islands, with other structures, in order to minimize the impacts of increased specialization in sectors with low valueadded, of drastic growth in the spatial concentration of certain economic activities, which would reinforce even greater regional inequalities in development, with regions with a large productive gap to the detriment of others with production complexity and diversity, the latter being normally holders of higher per capita incomes.

Additionally, the fact that some selected municipalities do not have an international trade agenda becomes a complicating issue, as the integration of these municipalities will marginally 
take place and, to a certain extent, dependent on the commercial relationship of low value-added. Policies for conducting and directing investment projects for these municipalities can improve their position in the face of RILA integration.

\section{FINAL CONSIDERATIONS}

The so-called Bioceanic Corridor (CB), Bioceanic Route (RB) or also named the Latin American Integration Route (RILA), is a transport corridor in the process of being implemented that has been providing a great debate. This project will certainly bring positive impacts and challenges as well. Therefore, to apply studies in this context is important to guide public policies that can maximize benefits and minimize negative impacts.

Hence, the main objective of this work was to analyze the productive structure of important municipalities that will be directly affected by the RILA path to understanding this process. To this end, we adopted regional indicators. The results of the analysis show a great spatial concentration of economic activities. In the industrial sector, the northeast regions and the surroundings of the capital Campo Grande stand out. The northeast region of the state also stands out in the Civil Construction sector and, together with the north-central part of MS, in the agricultural sector. In the trade sector, the southern region of MS stands out, close to Paraguay. In the services sector, there is a relative concentration in the capital and the extreme south of the state.

The results reveal a window of action by the public and private sectors to leverage the opportunities that will come from RILA. Public policies can allow an integration that enables gains in competitiveness for these sectors. The mere unplanned integration will potentially lead to the reinforcement of the regional inequalities highlighted in the State. In a more pessimistic analysis, the failure to elaborate an efficient planning, leaving itself unprotected from an articulated guiding public action, can make the threats of integration greater than the opportunities.

The massive entry of imported products can lead to a loss of competitiveness via state prices, as well as the expansion of inequality in the MS state, with a relatively greater gain for sectors such as agriculture and livestock (which, despite the high comparative advantage, tend to have a concentrated land ownership structure and generates fewer jobs than the industry). Still, the unplanned integration, just physical, through the connection of territories can reinforce trends such as the migration of productive structures to neighboring countries, as is the case of the Paraguayan maquilas.

Therefore, there is an urgent need for well-structured public policies, especially in the current context, in which RILA is still in the structuring phase. Such policies must include issues such as (i) Ensuring greater competitiveness to the sectors of the State, by expanding the innovative potential of companies and training the workforce; (ii) Establish trade agreements, especially within the Mercosul, to avoid integration problems (predatory competition, tax wars and the evasion of industrial parks) and foster complementarities and expansion of integration of regional production chains in the pursuit of elevation of added value and the creation of higher "quality" jobs. This policy would allow taking advantage of the positive externalities verified in agglomeration economies.

In this regard, it is important to foster the consolidation of a regional innovation system, as pointed out by Abrita and Silva (2019), i.e., to promote cooperation between the productive sector, companies, universities, and research institutes in search of products and services with 
greater degree of originality even protected through patents. Hence, it would be possible, at first, to reduce costs and increase competitiveness and, later, to add value and increase employment and income.

It is worth highlighting the need for further studies, to enable continuous verification of productive activities in the State and in RILA. For future research, we recommend expanding the analysis to encompass the other countries through which RILA will pass, as well as the effects of externalities that the route will create for states neighboring the MS state. (States through which they will be able to manage parallel integration routes and/or which will be incorporated into a larger integration corridor).

\section{REFERENCES}

ABRITA, M. B.; SILVA, W. G. A ciência e a tecnologia como possibilidades de desenvolvimento tecnológico da região centro oeste do Brasil. Boletim Goiano de Geografia, Goiânia, v. 39, p. 1-24, 2019.

ANSELIN, L. Interactive techniques and axploratory spatial data analysis. In: LONGLEY, P. A.; GOODCHILD, M. F.; MAGUIRE, D. J. Geographic information system: principles, techniques, management and applications. Nova York: John Wiley, 1998. p. 251-64.

ANSELIN, L. Local Indicators of Spatial Association - LISA. Geographical Analysis, Ohio, v. 27, n. 2, p. $93-$ 115, 1995.

ASATO, T. A.; MARQUES, H. R.; BUZARQUIS, R. M.; BORGES, P. P. Perspectivas da economia criativa e do desenvolvimento local no Corredor Bioceânico. Interações, Campo Grande, v. 20, número especial, p. 193-210, 2019.

AUDRETSCH, D. Agglomeration and the location of innovative activity. Oxford Review of Economic Policy, Oxford, v. 14, n. 2, p. 18-29, 1998.

BAPTISTA, R.; SWANN, P. Do firms in clusters innovate more? Research Policy, v. 27, n. 5, p. 525-40, 1998.

BRASIL. Ministério da Indústria, Comércio Exterior e Serviços. Comex Stat, [s.d.]. Portal para acesso gratuito às estatísticas de comércio exterior do Brasil. Available at: http://comexstat.mdic.gov.br/pt/home. Access on: 7 Dec. 2021.

CASSIOLATO, J. E.; SZAPIRO, M. Arranjos e sistemas produtivos inovativos locais no Brasil. Rio de Janeiro: Instituto de Economia da UFRJ, 2002.

CASTELLS, M. The rise of the network society. Oxford: Wiley-Blackwell, 1996.

CASTRO, J. C. P. Turismo como instrumento dinamizador do Corredor Rodoviário Bioceânico. Interações, Campo Grande, v. 20, número especial, p. 19-29, 2019.

CAVALCANTE, L. R. M. T. Produção teórica em economia regional: uma proposta de sistematização. Revista Brasileira de Estudos Regionais e Urbanos, Curitiba, v. 2, n. 1, p. 9-32, 2008.

CHESNAIS, F. A. A globalização e o curso do capitalismo de fim-de-século. Economia e Sociedade, Campinas, v. 4, n. 2, p. 1-30, 1995.

CONSELHO SUL-AMERICANO DE INFRAESTRUTURA E PLANEJAMENTO [COSIPLAN]. Historia. IRSA, [s.I.], 2018. Available at: http://www.iirsa.org/Page/Detail?menultemld=121. Access on: 15 Mar. 2020. 
CONSTANTINO, M.; DORSA, A. C.; BOSON, D. S.; MENDES, D. R. Caracterização econômica dos municípios sul-mato-grossenses no Corredor Bioceânico. Interações, Campo Grande, v. 20, número especial, p. 17992, 2019.

EHRNBERG, E.; JACOBSSON, S. Technological discontinuities and incumbents performance: an analytical framework. In: EDQUIST, C. Systems of Innovation: technologies, instituitions and organizations. Londres: Pinter, 1997.

ENRIGHT, M.; FFOWCS-WILLIAMS, I. Local partnership, clusters and SME globalisation. Paris: OECD, 2001. (Workshop paper).

FELDMAN, M. Location and innovation: the new economic geography of innovation, spillovers, and agglomeration. In: CLARK, G. L.; FELDMAN, M. P.; GERTLER, M. S. (Ed.). Oxford Handbook of Economic Geography. Oxford: Oxford University Press, 2000. p. 373-94.

FERREIRA, M.; CASTILHO, M. A.; OLIVEIRA, E. M. Brasil, Paraguai, Argentina e Chile/Rota Bioceânica: relações culturais no território vivido. Interações, Campo Grande, v. 20, número especial, p. 69-89, 2019.

FUIITA, M.; KRUGMAN, P.; VENABLES, A. J. The spatial economy: cities, regions and international trade. Cambridge: Massachussetts Institute of Technology, 2000.

GARRETSEN, H.; MCCANN, P.; MARTIN, R.; TYLER, P. The future of regional policy. Cambridge Journal of Regions, Economy and Society, Oxford, v. 6, n. 2, p. 179-86, 2013.

GLAESER, E. L.; KALLAL, H. D.; SCHINKMANN, J. A.; SHLEIFER, A. Growth in cities. Journal of Political Economy, Chicago, v. 100, n. 6, p. 1126-52, 1992.

GLASMEIER, A. Economic geography in practice: local economic development policy. In: CLARK, G. L.; FELDMAN, M.; GERTLER, M. Oxford handbook of economic geography. Oxford: Oxford University Press, 2000. p. 559-79.

HADDAD, P. R. Economia regional: teorias e métodos de análise. Fortaleza: Banco do Nordeste 1985.

ITAIPU. Dia histórico: Itaipu dá a largada à construção de mais uma ponte Brasil-Paraguai, agora no MS. Itaipu Binacional, [s.l.], 2020. Available at: https://www.itaipu.gov.br/sala-de-imprensa/noticia/ dia-historico-itaipu-da-largada-construcao-de-mais-uma-ponte-brasil-paragua. Access on: 14 Apr. 2020.

IAMMARINO, S.; MCCANN, P. The structure and evolution of industrial clusters: transactions, technology and knowledge spillovers. Research Policy, [s.l.], v. 35, n. 7, p. 1018-36. Available at: https://econpapers. repec.org/article/eeerespol/v_3a35_3ay_3a2006_3ai_3a7_3ap_3a1018-1036.htm. Access on: 29 Nov. 2021.

KEEBLE, D.; WILKINSON, F. (Ed.). High-technology clusters, networking and collective learning in Europe. Aldershot: Ashgate, 2000.

KRUGMAN, P. Development, geography an economic theory. Massachussetts: MIT Press, 1998.

MAILLAT, D. Milieux innovateurs et dynamique territoriale. In: RALLET, A.; TORRE, A. Économie Industrielle et Économie Spatiale. Paris: Economica, 1995. p. 211-32.

MARKUSEN, A. Áreas de atração de investimentos em um espaço econômico cambiante: uma tipologia de distritos industriais. Nova Economia, Belo Horizonte, v. 5, n. 2, p. 9-44, dez. 1995. 
MARSHALL, A. Principles of Economics. São Paulo: Nova Cultural Ltda, 1890.

ORGANISATION FOR ECONOMIC CO-OPERATION AND DEVELOPMENT [OECD]. Promoting growth in all regions. Paris: OECD, 2012.

ORGANISATION FOR ECONOMIC CO-OPERATION AND DEVELOPMENT [OECD]. OECD Regional Outlook 2011: building resilient regions for stronger recovery. Paris: OECD, 2011a.

ORGANISATION FOR ECONOMIC CO-OPERATION AND DEVELOPMENT [OECD]. Regions at a Glance 2011. Paris: OECD, 2011b.

PEREIRA, A. P. C.; ABRITA, M. B.; FONSECA, R. O. C. Circulação, desenvolvimento econômico e ordenamento territorial: elementos teóricos para análises de pesquisas sobre a Rota de Integração Latino Americana. Confins, São Paulo, n. 50, [n.p.], 2021.

PORTER, M. E. Clusters and the new economics of competition. Harvard Business Review, Brighton, v. 76, n. 6, p. 77-90, nov./dec. 1998.

PORTER, M. E. The competitive advantage of nations. New York: Free Press, 1990.

PORTER, M. E. Competitive Strategy: techniques for analyzing industries and competitors. New York: The Free Press, 1980.

SECRETARIA DE ESTADO DE MEIO AMBIENTE, DESENVOLVIMENTO ECONÔMICO, PRODUÇÃO E AGRICULTURA FAMILIAR [SEMAGRO]. Série histórica PIB-MS 2002-2016. Campo Grande: SEMAGRO, [s.d.]. SORENSON, O. Social networks and industrial geography. Journal of Evolutionary Economics, New York, v. 13, n. 5, p. 513-27, 2003.

STROPER, M. Desenvolvimento territorial na economia global do aprendizado: o desafio dos países em desenvolvimento. In: RIBEIRO, L. C. Q.; SANTOS JUNIOR, O. A. D. (Org.). Globalização, fragmentação e reforma urbana: o futuro das cidades brasileiras na crise. Rio de Janeiro: Civilização Brasileira, 1994.

\section{About the authors:}

Mateus Boldrine Abrita: Doctorate in Economics at the Federal University of Rio Grande do Sul (UFRGS). Master's Degree in Economic Sciences at the State University of Maringá (UEM). Graduated in Economic Sciences at the Federal University of Mato Grosso do Sul (UFMS). Currently full Professor of the State University of Mato Grosso do Sul (UEMS), teaching in the Geography Major, both Licentiate and Bachelor's degree. Advisor of interinstitutional relations and strategic projects at UEMS. Coordinator of the General Padilha Border Studies Center, and of the laboratory of efficiency and innovation in Mato Grosso do Sul's management (LAB-GEIMS). Vice-leader of the Group of Studies in Boards, Tourism and Territory (GEFRONTTER). Researcher of the Development's Structuralist Macroeconomics Group. E-mail: mateusabrita@hotmail.com, Orcid: https://orcid.org/0000-0002-3327-4556

Daniel Amorim Souza Centurião: Doctorate student in Economics at the West Virginia University, United States. Master's Degree in Economic Sciences at the State University of West Paraná (UNIOESTE). Graduated in Economic Sciences at the Federal University of Mato Grosso do Sul (UFMS). Currently works as an economist. E-mail: dancenturiao@gmail.com, Orcid: https://orcid.org/0000-0001-8372-6269 
Angelo Rondina Neto: Doctorate in Economics at the State University of Maringá (UEM), with partial completion at the Bryant University, from the United States. Master's Degree in Economics at UEM. Bachelor's degree in Economic Sciences at the State University of Londrina (UEL). Is currently an Assistant Professor of UEL's Department of Economics. E-mail: angelorondina@gmail.com, Orcid: http://orcid.org/0000-0002-2137-0751

Rafaella Stradiotto Vignandi: Phd Student at the University of São Paulo (USP). Doctorate in Economics at the Federal University of Minas Gerais (UFMG). Master's Degree in Economics at the State University of Maringá (UEM). Graduated in Economic Sciences at UEM. Professor of the Economic Sciences major in the Federal University of Rondonópolis (UFR). E-mail: s_rafaella@hotmail.com, Orcid: https://orcid.org/0000-0002-1867-7955 
